\title{
Direito e Ciência da Administração - A Reforma do Ensino Jurídico
}

\author{
ARNOLD WALD \\ (Advogado no Distrito Federal)
}

A

$\mathrm{S}$ aulas inaugurais não tinham no Brasil a originalidade revolucionária de que se revestiam no velho mundo. Eram aulas como as outras: a primeira aula do ano letivo. Não continham programas de renovação, idéias novas, aspirações ambiciosas. Não lançavam teorias nem princípios gerais. Eram apenas rotineiras e burocráticas, adotando os vícios do próprio ensino jurídico.

Coube ao Professor Francisco Clementino de SAN TIAgo Dantas quebrar essa tradição, ao abrir os cursos do ano de 1955, na Faculdade Nacional de Direito. Com a presença do corpo diplomático que comparecera adivinhando a amplitude que alcançaria a palavra do jurista, SAN TIAGo DANTAS apresentou, na aula inaugural, um projeto de reforma do ensino jurídico.

$\mathrm{Na}$ sua introdução, que constituiu o que êle pôde chamar uma "hernia sociológica", o civilista analisou a crise que atravessamos. Evocando a lição de ARNOld TOYNBEe, lembrou que a civilização progredia quando os "contrôles técnológicos e éticos" adquiriam maior eficácia, ampliando-se a sua esfera de ação, quando se resolviam os novos problemas, melhorando-se as soluções dadas aos antigos. Acontece na história que os contrôles morais se hipertrofiem, atrofiando-se os contrôles tecnológicos. Foi o que houve na Idade Média. Em outras ocasiões, a técnica se adianta excessivamente, reduzindo-se os contrôles éticos. E' o caso da nossa civilização hodierna.

A classe dirigente se mantém no poder enquanto os contrôles tecnológicos e éticos resolvem a maioria dos problemas. Quando não se encontram solucões adequadas para os novos probiemas e os problemas antigos são resolvidos por processos obsoletos, a classe dirigente se esfacela e alguns elementos das classes dirigidas, apelando para argumentos emocionais, procuram chegar ao poder. E' o reino da demagogia. Posteriormente, quando novas soluções racionais resolvem os problemas existentes, fortificando-se os contrôles teconológicos e éticos, uma nova classe dirigente se constitui.

A época atual se caracteriza pelo desequilíbrio entre os contrôles tecnológicos e morais. E' o que já Bergson assinalava. (1) Enquanto os autores

(1) V. também, ARNOld WALd, $A$ evolução do direito e a absorçâo da administração privada pela administração pública, $1953, \mathrm{p}$. 36 . 
apontam o declínio do Direito, ideal ético, assistimos ao desenvolvimento de certas ciências conexas, como a ciência da administração, a ciência econômica. O administrador hodierno não acredita mais no tabu da legalidade. Muitas vêzes, conscientemente, pratica atos ilegais que considera necessários para a realização do que êle entende ser o bem comum. E' preciso superar êste divórcio e devolver ao Direito o lugar que the pertence.

A função da Universidade, na presente crise, é da mais alta importância. O declínio do direito é em grande parte devido ao atrazo do ensino jurídico. O curso das faculdades de direito é expositivo, descritivo. E' um curso de explanação, de exposição dos institutos jurídicos. Tal exposição, embora necessária e indispensável, não é o fim colimado. Necessário é dar uma formação jurídica, criar os mecanismos do raciocínio jurídico, passar da aula-conferência à resolução dos problemas jurídicos, do text system ao case system. Assim, partindo da crise da época, San Tiago Dantas chegou ao ponto nevrálgico da transformação do ensino jurídico.

A necessidade apontada não o era pela primeira vez, mas, pela primeira vez, um esquema de projeto de reforma era esboçado diante da congregação da Faculdade Nacional de Direito e do Ministro da Educação e Cultura.

A luta para transformar o ensino superior, passando-se do monólogo ao diálogo, do aluno-aparêlho receptor ao estudante colaborador dos mestres num esfôrço comum, embora dirigido, para esclarecer as noções e resolver os problemas apresentados, data dos últimos quinze anos.

Nos congressos jurídicos debatera-se a matéria. Em 1941, o Professor LOURENÇo Filho publicava na "Revista do Serviço Público" (2) uma excelente monografia sôbre $A$ discussão nos trabalhos de seminário. A partir de 1949, um grupo de estudantes da Faculdade Nacional de Direito, iniciava um movimento para a organização de seminários. Em artigo então publicado na "Epoca" (3) ressaltavam que: "Os trabalhos de seminário continuam a ser, porém, uma experiência desconhecida para a maioria dos alunos, do mesmo modo, aliás, que outras atividades escolares previstas no regimento da Faculdade.

Em lugar de trabalhos de investigação e análise, temos, assim, à semelhança do que ocorre na escola secundária, um ensino predominantemente menomonista ou, quando muito, intelectualista. Nossa formação profissional se ressente, por conseguinte, de inúmeras deficiências, o que explica o insucesso de tão elevado número de bacharéis na vida prática. Ora, é nossa convicção que a preparação técnica e metodológica do homem de estudo-função primordial de um seminário - poderia contribuir decisivamente para sanas muitas dessas deficiências, possibilitando-nos a realização de um curso jurídico muito mais completo e proveitoso."

(2) "Revista do Serviço Público", novembro de 1941.

(3) A "Época", n.o 192, julho 1951, p. 114. 
As primeiras tentativas foram esboçadas na Faculdade Nacional de Direito pelos Professôres Haroldo Valladão, San Tiago Dantas e DemosTHENES MADUREIRA DE PINHo a fim de ser dado ao aluno um papel não apenas passivo, mas também ativo, visando-se não só o conhecimento dos institutos jurídicos, mas ainda a formação de um raciocínio jurídico, procurando-se permitir ao aluno de enquadrar determinadas situações de fato dentro das normas legais competentes para resolver a controvérsia.

Almoços e posses foram ocasiões em que a campanha procurou sair do estado latente em que se encontrava.

Em 1952 e em 1954, quando tomavam posse como diretores da Faculdade, respectivamente, os Professôres CASTRo REBEllo e ARNoldo MEdeiros DA FONSECA, saudando-os em discursos que ficaram nos anais da universidade, Demosthenes Madureira de Pinho lembrou a necessidade de uma reforma ampla, provocando o seu apelo a decisão tomada pelo Ministério da Educação de convocar uma reunião de professôres de direito para discutir o assunto.

A palavra de SAN TIAGo DANTAS não se limitou todavia a constatar o fato, a indicar globalmente o remédio. Apontou o caminho a seguir. Mostrou que o curso não devia se limitar às aulas-conferências, devendo passar para o primeiro plano o estudo das decisões judiciárias, a solução de casos hipotéticos. A medida que a técnica se aprofunda, o sistema de opção se impõe. Assim sendo, ao lado de um curso geral que desse ao advogado o mínimo de subsídios de que necessita para a sua carreira profissional, propôs o eminente civilista a divisão dos cursos em quatro seções de acôrdo com as especializações preferidas. As seções visariam respectivamente a formação de comercialistas, de penalistas, de especialistas em direito administrativo e de bacharéis especializados em ciências econômicas e sociais. Os membros de cada seção fariam um curso regular compreendendo as outras matérias e desenvolvendo especialmente a de sua especialização. Quanto aos pertinentes à última seção, poderiam seguir cursos em parte nas faculdades de ciências econômicas e de filosofia, o que, diz muito acertadamente SAN TIAGo DANTAS, acabaria com a política de isolamento e insulamento das faculdades, dando certa unidade à universidade. Igual coordenação poderia ser feita entre os especialistas de direito administrativo e a Escola de Administração Pública.

A parte prática, passaria a ter proporções muito mais vastas. Mais longo seria o tempo diário passado na faculdade pelos estudantes devido aos trabalhos de seminário, que devem durar no mínimo duas e no máximo três horas.

A reforma necessita incontestàvelmente, para ser realizada, de meios materiais importantes: turmas menores para os trabalhos práticos, numerosos assistentes etc... Mas ela corresponde a um imperativo do nosso tempo, a uma necessidade da nossa sociedade.

E' a contribuição que o jurista pode dar para o restabelecimento do equilíbrio entre contrôles éticos e tecnológicos, para que o Direito tenha o lugar que the cabe na escala dos valores.

O discurso de San Tiago Dantas é um grito de alarma que comove pela sinceridade e pela clarividência do seu autor. E' um homem que vê todos 
os inconvenientes do poder de inércia. E sai à praça pública para, revestido de tôda a sua autoridade, indicar a única solução para que nossa juventude tenha uma formação digna dela, para que o Brasil se possa libertar da corrupção moral em que está mergulhado, para que a lógica jurídica e o espírito cívico dominem novamente o nosso povo.

Para quem está a observar as conjunturas da vida brasileira, as dificuldades existentes justamente devido ao desequilíbrio entre contrôles tecnológicos e morais, os embates entre o que os administradores entendem como bem comum e os que os juizes conceituam como direitos e garantias individuais, o discurso de SAN TIAgo DANTAS tem uma nota patética, parecendo lembrar o dever dos juristas na presente hora, e dando a impressão de um sinal de S.O.S. lançado por um navio ao largo e que os outros repetem e retransmitem, sem grandes esperanças de poder salvar o náufrago.

A reforma jurídica é uma pedra a mais na estrada que há de nos levar a um novo equilibrio de fôrças, a uma nova mentalidade, para que o Brasil possa solucionar os seus problemas e progredir.

\section{TÉCNICA DA DISCUSSÃO EM GRUPOŚ}

O grupo de discussão deve compor-se de pessoas do mesmo nível intelectual, com estudos semelhantes. Sem o que, não se entenderão. Tratando-se de adolescentes - que sejam de pequena diferença de idade, reunidos por afinidades naturais de temperamento e de simpatia recíproca. O número pode ser variável. Nossa experiência tem demonstrado, no entanto, que os grupos de estudo não devem conter menos de cinco elementos, nem mais de nove. Com menos de cinco, o trabalho de cooperação seria precário, os "pontos de vista" pouco numerosos. Com dez ou mais, a ordem dos trabalhos já exigiria organização formal, com perda de tempo. Ainda mais, haveria "galeria", circunstância a levar-se em conta com adolescentes. Nessa idade, pensa-se mal sòzinho; pensa-se pior ainda, em grupos muito numerosos .

Cada grupo deverá ter seus trabalhos coordenados por um chefe. A experiência mostra não convir que chefia seja permanente ou efetiva. Ao contrário, deverá ser rotativa, sucedendo-se nela todos os membros do grupo, um em cada semana, por exemplo. Ao chefe incumbirá distribuir os trabalhos preliminares; abrir as discussões; encaminhá-las como um presidente de assembléia, velando pelas regras, mas sem formalismo; reduzir a escritc o andamento do debate, e propor, por fim, a redação de um relatório. Êsse relatório terá a forma de esquema, não de ata. Deverá fixar a redação conveniente do problema, a definição de têrmos, os argumentos favoráveis à conclusão assentada, e a indicação das fontes de estudo de que o grupo se serviu. Dève ter, no entanto, a sua opinião, que exporá por fim, e que será tomada na mesma consideração em que as opiniões dos démais parceiros o tenha sido. (Prof. Lourenço Filho, "A Discussão nos trabalhos de Seminário" - In "Rev. Serv. Público", vol. IV - N. 2 - novembro de 1941, pág. 168. 